perifèria

Número 17, diciembre 2012

revistes.uab.cat/periferia

\title{
Photography as a participatory method in visual anthropology
}

\author{
Jonatan Kurzwelly \\ MA Anthropological Research student \\ University of Manchester ${ }^{1}$
}

\begin{abstract}
In this paper my goal is to theoretically ground, and discuss the possible uses of, participatory photography in social and cultural anthropology. However, before discussing photography, I consider the subjectivity of sight and make a claim of multiplicity of realities/perspectives

I then briefly outline some previous statements on photography and its connection to reality and informational value. Then I propose a way of combining the theory of vision and perspectivism described earlier with theories of photography to create a new understanding of the informational value of photography. I will also briefly discuss the connection between language and photography.

The second part of this essay first discusses several examples of visual participatory projects and some issues emerging out of them. Later I give an introduction to the project "Views from inside" which I conducted together with Maria Lebioda. I discuss several issues of participatory photography methodology and things that need to be taken into account while planning such projects. I provide examples of photos made during this project.

The goal of this essay is to introduce a certain way of thinking about photography, and to discuss some aspects of it. It is not a complete manual, and there are many things that are not discussed here, but I hope this essay may be useful to those who are planning a participatory photography project.
\end{abstract}

Key words: participatory photography, methodology, multiple realities.

\section{Resumen}

En este artículo mi objetivo es discutir la teoría y los posibles usos de la fotografía participativa en antropología social y cultural. Previamente, pongo a consideración y describo la subjetividad de la vista y presento el concepto de múltiples realidades/perspectivas.

En la primera parte, expongo algunas afirmaciones sobre la fotografía y sus conexiones con la realidad y el valor informativo. A continuación, propongo una posibilidad de combinar la teoría de la visión y el perspectivismo, descrito anteriormente, con teorías de la fotografía, creando una nueva compresión del valor informativo de las imágenes.

\footnotetext{
${ }^{1}$ Email: jonatan.kurzwelly@gmail.com
} 


\section{perifèria}

Número 17, diciembre 2012

revistes.uab.cat/periferia

En la segunda parte del artículo, describo en primer lugar algunos ejemplos de proyectos previos de fotografía participativa, así como diferentes aspectos relacionados con ellos. Más adelante, presento el proyecto "Views from inside" (miradas desde el interior) que desarrollé junto con María Lebioda. Abordo varios aspectos metodológicos que han de tenerse en cuenta en el diseño de un proyecto de fotografía participativa. Como muestra, incluyo fotografías tomadas durante el proyecto.

El propósito de este artículo es introducir una nueva compresión de la fotografía, y debatir algunos aspectos de la misma. No pretende ser una guía completa, pues hay muchos aspectos que no se abordan en el texto. La pretensión es presentar una experiencia que pueda ser útil para cualquier persona que desee hacer un proyecto de fotografía participativa.

Palabras clave: fotografía participativa, metodología, múltiples realidades.

\section{Perception. Perspectives. Realities}

Seeing is a subjective experience. It has been many times repeated within social and cultural sciences. What does the subjectivity of sight implicate? Seeing, as one of many integral body functions, forms and constitutes subjective realities. The idea of individual, subjective realities will be central in this essay.

Dale Purves and Beau Lotto in "Why We See What We Do Redux" (2011) criticize the previous approaches in which vision is explained as "an accurate representation of the physical world" (Ibid, 3). Analyzing all aspects of vision (lightness, brightness, color, form, distance, depth, and motion), they claim that direct information about the world is unavailable. “(...) despite our overwhelming impression that we perceive the world as it is, what we in fact see on this basis is not a facsimile of the physical world that is occasionally misleading (causing visual "illusions"), but a subjective world fully determined by associations made between images and successful behavior over the course of species and individual history" (Ibid, ix). The physical context (physical parameters) is interpreted by empirical processes which link images with behavior by trial and error interactions with the environment. In other words, what we see is a result of how we learned how to see. Perceptions we create from the retinal images are subjective constructs. ${ }^{2}$

As the visual perception of each individual can differ dramatically - and examples can be given for other senses than sight $^{3}$ - we can say that the world of each individual is different. There is no epistemologically objective reality, and it is

\footnotetext{
2 For examples of differences in individual perception see pages 9-12 in my BA thesis: http://www.od-wewnatrz.pl/public/files/pdf/JonatanKurzwelly-praca_licencjacka.pdf
} 


\section{perifèria}

Número 17, diciembre 2012

\section{revistes.uab.cat/periferia}

impossible to define with our subjective perception whether there is one objective ontological reality. We have access only to "our reality," through our body ${ }^{4}$. Nobody is an "outside viewer." That is why I will speak about a multiplicity of realities. Each person, each body, has its own reality or, in other words, its own perspective. The perception and understanding of objects and of others will differ in different perspectives. Those realities, those perspectives, can have many common points and similarities, which in terms of "what is" (the meanings) are intersubjective agreements. The perspective is defined by the body and previous experiences, as well as by different processes and relations, which people establish with objects and others.

To give an example of different perspectives we can think about the different notions of some concrete objects or places - for example, a staircase in an apartment building. For one person these stairs may be a "normal" way to cross between different levels in a building. For a child that likes to play there, it might be a playground or a place of jumping and sliding down the handrail. For an older person with walking difficulties, it might be an insurmountable obstacle. But for a mouse or an ant, it might not have a function at all. So what relativism might define as the same object seen in different ways (one reality, different views), perspectivism would define rather as a multiplicity of objects and meanings in different realities connected with different bodies. ${ }^{5}$

According to Tarzycjusz Buliński and Mariusz Kairski (2011:297), “The body creates perspective, perspective creates the world, the body "verifies" its authenticity and asserts itself in it through its experience. Entities with different bodies, have different perspectives, they see the world and other beings with different bodies in their own way. In other words, they are in different realities".

\footnotetext{
${ }^{3}$ I do not claim that sight is a dominant sense; it is not my intention to be oculocentric. As this is a short paper on photography, I use sight in order to make my theoretical point, compare human eye perception with camera and embed photography in perspectivism. I do believe that all senses are related, and photography is not only visual, and can provoke other sensual experiences or memories. Elizabeth Ewart (2008) writes, using as an example the case of the Panará people, seeing also means being seen (vision and visibility), and being seen involves the whole body.

${ }^{4}$ I do not divide body and mind. Thus what I call body is an assemblage of the physical shape and the ways of being (that are also related and depend on each other).

${ }^{5}$ I use a simplified modification (excluding the cosmological "one culture") of what is called Amerindian perspectivism. For more about perspectivism see Viveiros de Castro (1996 and 1998), Stolze Lima (1999) and Kohn (2007).
} 


\section{perifèria}

Número 17, diciembre 2012

revistes.uab.cat/periferia

The existence of the stairs is also dependent on the perspective, according to Tânia Stolze Lima (1999:117): “Point of view implies a particular conception according to which the world only exists for someone. More precisely, whether it is a being or an event (...) what exists, exists for someone. There is no reality independent of a subject."

And of course, it is important to mention that the individual perspectives change constantly as our bodies change and as we gain more experiences. The staircase may be perceived similarly, if some entities who share similar experiences, and intersubjectively agree about the meaning, establish a similar relation. However after a dramatic change of the body, or after some new experiences, one may change one's perception of the staircase.

\section{Photography. Truth and informational value. Language}

How can we locate photography in all this complexity of perspectives? In my opinion it can help as a tool of translation between different realities. What is, and what can be, the informational value of photographic pictures?

At the very beginning of photographical techniques, when the first images were created, there was a belief of capturing objective reality. Photography was seen as a physical and chemical process that can provide truth. The goal was to create images of nature, captured without the intervention of an artist. The images were considered created by physics and chemistry, by the laws of nature. "The sun, eye of the world, was made an assistant of technology" as it was written in the first text about daguerreotype (Jules Janin, in von Brauchitsch 2004:28). Or as François Dominique Arago claimed, when he wrote about the possible use of daguerreotypes in Egyptian research: "the images are drawn with the rays of light" (Arago, in Sikora 2004:19).

The images have created themselves. Henry Fox Talbot, the inventor of the calotype process, wrote about one of his pictures: "It is, I believe, the first case of a house, which painted his own portrait" (Talbot, in von Brauchitsch 2004:25). There was the belief in images creating themselves, or in nature reflecting itself in pictures. The role of photographer was perceived as marginal, and pushed to a role of a technician.

The so-called "enthusiasm," the belief in capturing objective reality, encountered trouble from the beginning. The photographers knew that by different exposure and 


\section{perifèria}

Número 17, diciembre 2012

revistes.uab.cat/periferia

focal length settings they can influence the final effect. Very soon after the first photographs had been taken, in the 1850s, Oscar Rejlander and Gustave le Gray created their works, using negative modification and collage techniques. Gray presented sea landscapes, using different lighting for the water and for the sky. Rejlander used photomontage to create pictures made of many negatives, such as “Two ways of life," 1857. Those techniques have shown that photography can be modified in many different ways, and depends highly on its author.

Later many critics of photography emerged, who argued in many different ways that photography does not reflect reality and that it is subjective and susceptible to manipulation. Discussions emerged about the informational potential of photography, and for many critics photography was not a reliable source of information. Many of them refer to the inability of objective information in relation to a single given physical reality (outside of the subjective human). We know already that such an information is not available at all.

One of the most famous authors who wrote about photography was Roland Barthes. After his mother Henriette Barthes died, he wrote the well-known "Camera Lucida" (Barthes 1996 [1980]) ${ }^{6}$. It is a book that both shows his grief and at the same time discusses the subjectivity of photography. As he tries to deal with the many meanings that photographs can be given he searches for the nature of photography. For Barthes" the "photograph is always carrying its referent with itself" (Ibid.). To him a pipe is always a pipe, even though it might refer to different time (refer to what-was), location, and different feelings. Barthes had not escaped the relativist problem, and is referring to one physical reality. If we employ the perspectivism theory, we will know that the pipe, whether seen directly or in a picture, might not always be a pipe, just like in the above example of a staircase. Barthes also claims that photography is somehow reproducing something that happened only once, and will not happen again existentially (Ibid.). In claiming this he accepts the linear notion of time, which is problematic as photographs may also reproduce something that is or will be repeated.

\footnotetext{
${ }^{6}$ I have used a pdf copy of this book, therefore I'm not mentioning page numbers as it would be misleading.

${ }^{7}$ I only focus on part of the photography-reality subject described by Barthes and Sontag, and it is a huge simplification of their thesis. I use it only to emphasize the "one reality" assumption, and I do not want to underestimate their works nor their contributions.
} 


\section{perifèria}

Número 17, diciembre 2012

revistes.uab.cat/periferia

Susan Sontag in her writings (Sontag 1986:140) also reproduces the idea of a single objective reality. She claims that a photograph is not only an image and interpretation of reality, but also a "trace," something that is reflected directly from the objective world. She separates painting from photography, claiming that painting is always only an interpretation, and photography registers the light waves reflected from objects. That is why for her photography has got the "trace" in itself, a thin connection with the objective reality, something that she compares to a footprint or a death mask. I disagree, as we know the photographic process is determined by many factors; we use different lenses, which modify the qualities of light waves. We can use different mechanical and chemical or electronic processes, which register the light waves in different ways. We use different methods of processing and editing the information registered in this process, and then we can use different methods of presenting the image. Moreover as Dale Purves and Beau Lotto (2011) argue, all the image qualities are something we learn to see, just as we learn to see photographs. Photography as a process has no connection to any objective reality. There is no "trace" of an objective reality.

Tom Gunning, cinematologist from the University of Chicago, in a much more recent publication (Gunning 2004) has written about the subject of indexicality ${ }^{8}$. First he demonstrates how both analog and digital photography, by action on images (for example using a Photoshop program), can undermine or undo the indexical. He also tells us that the recognition of a photographic image as an image of its object depends not only on the indexicality but also on the viewer's evaluation of accurateness. "The image must be legible in order to be likened to its subject" (Gunning 2004:41). For Gunning the "truth claim" relies on both indexicality and visual accuracy. He gives the example of specific photography manuals written for crime scene police photographers, which draw on constructs of both indexicality and accuracy. However using the empirical vision theory and perspectivism I consider "indexicality" as a construct, a social agreement, about some certain belief of "truth" that can be put into photographs. The relationship between the object photographed and the resulting image is only an assumed relationship that people assign to photography. In the same way as there is no access to objective reality in human eye vision, there is no direct access to objective reality in photographs. The police photography manuals are an agreement (made by those who created the

\footnotetext{
${ }^{8}$ Using the term "indexicality" by Charles Peirce, he refers to the relationship between the photographed object and the resulting image.
} 


\section{perifèria}

Número 17, diciembre 2012

revistes.uab.cat/periferia

rules and those who accept them) of which conditions of creating images will make them legally reliable; an agreement on a specified process that invokes similar relations with those photographs. To me "indexicality" means only an intersubjective agreement about the belief that a certain photographic image can be somehow related (by experience) to people's realities, and that the relation between image and reality will be similar for different individuals. However, this does not undermine the informational value of photography, knowing that all (not only photographical) "truth claims" will be based on similar intersubjective agreements.

In this essay I propose to combine the aforementioned vision and perspectivism theories with photography. For our purposes, we should not see photography as a subjective tool that is providing some unreliable images of objective reality. We shall see it as a tool that can provide information about various realities, a source of information in between perspectives and realities. Photography-making techniques or printed images should not be separated from the author, or from the moment when the picture is taken.

The problem of many critics of photography was that they criticized the photographic pictures themselves for lack of objectivity and for information manipulation. If we see a photographic picture and consider it as a separate autonomic unit, we can only see and understand it through our perspective, through our experience and through our understanding of what we see on the picture. What is important in order to use photographic pictures as sources of information about other people's perspectives is their description of the picture, of the picture's context, and about the motives and the meanings the picture has for the author of the picture (a kind of a deixis, an indication).

A good example is the phenomenon of "Cat Cam", which has become very famous on the Internet. A Cat Cam is a small photo camera, mounted on the neck of a cat, continuously taking pictures every minute. Some might think that the pictures as a result contain information about the particular perspective of a cat. But the retinal images the cat is getting differ greatly from the images recorded by the camera, and more important, we have absolutely no access to information about how the particular cat understands what it sees or what relations it has with objects or other beings. With this method we can only look in the same direction in which the cat is seeing, but we see all the objects in the way we learned to see them, through 


\section{perifèria}

Número 17, diciembre 2012

revistes.uab.cat/periferia

photographs. We cannot ask the cat what it is seeing at this particular moment, or what it sees at the images. We can only assume it, using our knowledge and experience about cats. That is why, in order to get information about other perspectives, the explanation (combined with our own experience interacting with others) plays a crucial role.

As I have mentioned above, the ways that people explain and describe photographic images play a crucial role in the value of the information given by participatory photography. The strength of using both photography and language (discussion or interview) lies in the inability to fully define their relation. A great explanation is given by François Soulages (2007:295-301). At first it might appear that language by the use of acoustic symbols (signifiant) refers to a multiplicity or to one given thing (signifié), and that photography relates always to one given thing (this exact tree in this exact picture). If so, photography can share meaning through immediacy of image. But as Soulages explains, to be able to understand photography we also use certain codes. Some artistic photographs can be seen as symbols or allegories. Advertising photographs can give the (fake) informational value about objects and provoke imagination and consumption. Family photography can provoke memories and feelings. Travel photography can provide evidence (“I was there"). Passport pictures can be seen as an evidence of who I am by referring directly to me; but none of those categories are set and defined. The perception and understanding of photographic images depends on the viewer. The same portrait for someone can have a high emotional value (something unspoken), and for another person it can be only a description of some human, a legal proof. In this case a verbal explanation can help to understand the meaning of the portrait to both of them to understand the picture from different perspectives. Also because language is not the only means by which communication takes place and knowledge is transmitted, I believe that photos can enrich ethnographic writings and should be used much more often.

\section{Participation. Research examples}

Photography, an invention ascribed to both Daguerre and Talbot, served from the beginning in many different ways. It was also used as a tool of showing cultural diversity, of the "others," giving evidence of their existence or explaining their way of being (for instance the famous photographs by Edward Curtis). It has been present in social and cultural anthropology in many ways, from photographs that 


\section{perifèria}

Número 17, diciembre 2012

revistes.uab.cat/periferia

have been used as additions to "decorate" research (as in the work of anthropologists like Bronisław Malinowski, Franz Boas, Edward Evans-Pritchard and many others), to the use of visual techniques as a basis of methodologies and the rise of the subdiscipline visual anthropology. In this essay I will present several examples of the use of visual participatory methods instead of focusing on history of photography or history of visual anthropology ${ }^{9}$.

What does participation change in the research situation? Participatory methods have often been praised for escaping from the authoritative position of the scientist, for the "attempt to decrease the power differential between the researcher and the researched" (Packard 2008:63).

"When the photographs are taken as a result of collaboration, they combine the intentions of both the ethnographer, as well as the informant, and provide a result that is an effect of negotiation" (Pink 2009: 99).

The intentions of the anthropologist and his or her research partners should be revealed during discussions. In such a process the created pictures could serve both the anthropologist (for his publications or exhibitions) as well as the participants (for family albums, as souvenirs, or photos which they can exhibit to other community members). The project participants may as well enjoy the idea that their pictures will be later shown as a representation of their reality (see the further examples in the "Views from inside" project). In this approach it is they, the participants, who decide what to present - they are given more authority. Does it really change the relationship between power and knowledge creation? Josh Packard, a sociologist from Vanderbilt University, has questioned this issue. "In order to equalize power relationships in a project, technical competencies must be similar. An unequal power dynamic is immediately and irrevocably established the moment the researcher must instruct a participant on how to operate a piece of equipment" (Packard 2008:64). On the other hand, the researchers are those who are taught about the participants' lives, so in this aspect the participants have the authority of knowledge. However it is still we, the scientists, who have the power to

\footnotetext{
9 The history of photography in anthropology is discussed in more detail in Elizabeth Edwards (1994, 2001,2011 ). The history of visual anthropology is discussed in Banks and Ruby (editors, 2011). Contemporary developments and methods are presented in Banks (2009 [2001]) and Pink (2009 [2001]). History of photography in general and in connection with art is discussed in more detail in Boris von Brauchitsch (2004), or in the comprehensive volume edited by Michel Frizot (1998).
} 


\section{perifèria}

Número 17, diciembre 2012

revistes.uab.cat/periferia

"give authority." For us it is still an investigation; we want to obtain some particular knowledge and use it for our purposes. For all those reasons, in my opinion, the authority of the researcher does not decrease, but the authority of research partners increases. This is not a rule and it might differ, depending on personal attitudes and the exact methodology. It can as well be used without any concern about the power dynamics. I will give examples of such differences in some visual participatory projects in order to underline different partnership relations, but also to briefly explain the different methodologies employed, the information obtained, and the technology used (filmmaking, drawing, painting and photography).

A good example is a participatory photography project with children by Paula González Granados, described in her doctoral thesis (2011). She conducted two workshops, one in Shared Schooling Unit in Tarragona (Unidad de Escolarización Compartida en Tarragona), and the second in a Community Center in Mexico City (Centro Comunitario en México DF) with children and adolescents from 10 to 17 years of age. Interviews have been conducted with all participants based on photographs made individually outside of the workshops. As a result public expositions of photos have been organized (Ibid, 150-152).

During the workshops the main methodology consisted of "photographic walks," and individual photography. The walk places were decided between the researcher and the participants, leaving the children free to take photos of the space, of people in it, and of each other. During the walks Paula was there only to help with technical problems, not to suggest what to capture in photos. The anthropological goals of the walks were: to observe the dynamics and reasons behind choosing a location that is "good for photographing"; to observe the interactions during the walks and the ways of taking pictures; to see what the participants were interested in, including how they posed in front of the camera (their auto-representations); conflicts that arose while using the cameras; and finally to analyze the outcome of the images in relation to all the previous information. (Ibid, 195-202).

The participants also made photos beside the walks. They were given cameras for 2-7 days, with the goal to explain who they are and what their daily life is like. Later interviews were conducted on the basis of those photos (Ibid, 202-210). Those interviews are crucial, because Paula González Granados' interpretations and valorizations of the photos were different from those of the participants. Completely different meanings have been revealed. Very important during such interviews is 


\section{perifèria}

Número 17, diciembre 2012

revistes.uab.cat/periferia

confidence, because some of the young people were worried that some photographs (for instance photographs of them smoking marijuana) might be exposed to their parents or teachers. That is why I think that all possible ways of using photography and information has to be discussed and agreed before starting such a project ${ }^{10}$.

Participatory photography has also been used in other contexts beyond anthropological research. There are many examples and I will just briefly mention some of them. First I want to mention the film "Born into Brothels" (2004) by Ross Kauffman and Zana Briski. The work presented in the film consisted in teaching photography to 9 children of a red light district in Calcutta, India. The aim was to try to "look through their eyes." The project differs from the previously described one because the focus is on the pictures as the final outcome, on the aesthetic value. The children were taught composition rules, and it was an "art photography class," more so than just using photography as a matter of communication. Later some photos were chosen and presented in an exhibition outside of the context of their creation. It was connected with an aspect of a "fight for a better life" for the children. This is an example of a very unequal power and knowledge relation. The authority of the children is respected only in a very limited way, and the authority of their parents is sometimes not respected at all.

Participatory photography also can be used for "art therapy." A good example is the work of Marc Pataut (Pataut in Soulages 2007:182-196) in a psychiatric clinic in the suburbs of Paris in the 1980s. He wanted to go beyond a simple reportage, and at the same time the clinic wanted to make a form of therapy with the use of photography. He gave cameras to children without any instructions on how to use them. They were able to experiment with the camera, to play with it, to use it in their games. Afterwards Pataut observed the fascination of the children when they saw the appearance of images on paper in the dark room, and how the children used the outcome images (the way they made personal albums, spoke to the photographs, or destroyed them). Later an exposition of these photos appeared in the hospital. Pataut is an artist photographer rather than a social scientist, and therefore his methods and goals are different than those of a researcher. The

\footnotetext{
${ }^{10}$ The methodology of this research project is highly interesting, well developed and described. For those who are interested in methodological details and the project results I recommend the original dissertation (González Granados 2011).
} 


\section{perifèria}

Número 17, diciembre 2012

revistes.uab.cat/periferia

project provides much information about those children and their relations with what they have photographed, although participation occurs at a very limited level.

\section{The project "Views from inside" (2010)}

My idea of conducting a participatory photography project developed before starting my anthropological studies, during my summer "Work and Travel" vacations in Venezuela in 2008. I realized how differently my photographs are perceived by my friends and family in Poland and by people from Gran Sabana. However, the main inspiration was my contact with Carlota Duarte ${ }^{11}$, the founder of Archivo Fotográfico Indígena, a photographical project in Chiapas (Mexico), in which local Maya people have been given the opportunity to use photography by themselves. At the beginning I wanted to create a participatory project, but more in terms of a collaborative art project than as a social science research project. Now I would describe the first version of the project concept as a rather naïve one. The project developed in different ways, although the location was partially maintained. During the very first month of my studies of cultural anthropology, I went to discuss the idea with one of my teachers - Dr. Jacek Schmidt - and he helped me to change it into a research project using anthropological methodologies. Later, Maria Lebioda, another anthropology student, joined the project, and we cooperated at all levels of preparation, including fundraising and later the field work.

With the help and advice of our professors, we prepared a research plan. We wanted to do an extensive field work project in Chiapas. We planned the methodology; we wanted to create "portraits from inside" of the participants. Our methodology and our plans changed a lot once we arrived in Mexico. The first change happened through the influence of Jesus Ruvalcaba Mercado and Aleksandra Iciek (scholars at the CIESAS, Mexico), who convinced us to do an even more extensive research project and to go with them to the region La Huasteca, where we stayed in a Nahua village (Hueycuatitla) and realized the first part of our research. Then we went as planned before to the Highlands of Chiapas, where we stayed at a Maya-Tzotzil village (Las Limas). Afterwards we moved to Guatemala to a Maya-Kaqchiquel village called San Jorge la Laguna, near to Lake Atitlan. At those two locations, we worked with friends of Witold Jacórzyński (professor at CIESAS, Mexico).

\footnotetext{
${ }^{11}$ Witold Jacórzyński contacted me with Carlota Duarte. Witold has helped with this project at all its levels, and without him the project would not take place.
} 


\section{perifèria}

Número 17, diciembre 2012

revistes.uab.cat/periferia

It was our first field research (we went there during summer vacation after the first year of studies), and we made many mistakes; we had to confront our expectations and the little anthropological knowledge we had, as well as the difficulties of communication between us and the participants with their very different perspectives. We had to learn how to speak with people, and fortunately all people we worked with were very friendly and had enormous patience with us. I believe, however, that the mistakes we made were useful for the purpose of this paper, as I am now more conscious about what can go wrong and what to avoid in further projects of this kind.

The "portraits from inside" consisted of a general interview with each of the participants about their work and free time, their favorite activities, their living surroundings, joys and sorrows of daily life, and their plans for and dreams about the future. In retrospect I think it was a mistake to do questionnaire interviews, as this imposes our values of what is important and interesting. Rather, we should have asked the participants to introduce themselves, giving them a free choice of what to talk about. However, at the beginning we followed the questionnaire strictly, but many times the answers were different than what we had expected (for example: the idea of what is "work" was completely different). They did not understand what we wanted to know, so we experimented with making the questions more open, more as indications than concrete demands of responses. All interviews were recorded and later transcribed. After the interviews we explained the use of an automatic digital camera to the participants (we explained only how to turn the camera on and off and how to take a picture; we did not say anything about composition or aesthetic issues). Then we asked them to make photos that could introduce us to their joys and sorrows, to things they like or dislike in their environment as well as what seems to be important to them. We accompanied them while they took the pictures, and unfortunately, we also started taking pictures. I think this was a mistake. By taking pictures ourselves, we unconsciously gave examples of what kind of photos can be taken and from which angles, and generally how a camera can be used. After the picture sessions we looked at all the pictures together with the participants. We asked them to describe the pictures they took and to tell us why they took them. We asked them to show us which pictures they liked most. Then we invited each participant to take a portrait photo of themselves in the surroundings and with the people of their choice. After conducting the project in each village we printed photos of each participant and 


\section{perifèria}

Número 17, diciembre 2012

revistes.uab.cat/periferia

gave them to the authors as a small gift. The whole process with each person took at most several hours, which was a mistake. I am sure that if we would have spent more time with each person, if we repeated the photo shootings, the quality of the obtained information would have been better.

There are several methodological issues of participatory visual research I want to discuss here with the use of examples from the project "Views from inside." One of the first things to do while planning such a project is to establish the purpose of it for both researchers and participants - the "level of participation." For our project, the purpose was to investigate the method itself and its possible use in ethnography, and how it can become a method of communication just as important as language. As I already mentioned, we prepared the methodology, the questions, and the subjects of photos before starting the project. This is one aspect I want to critique. In participatory methods, the researcher(s) should work from the very beginning with the people they want to get to know better. The participants should decide about the subjects of photography, and the researchers should only give propositions. This way, they are given a voice and the possibility for self-presentation. If we are interested in one specific topic or part of life of our participants, it should also be discussed with them. The authority of the researcher in the relationship cannot be eliminated during such actions, but I believe that this way more authority is given to the persons we work with. Although it was still us, the researchers, who initiated the photography situations, the people mostly seemed to enjoy it. They liked the idea of their photos being presented in far-away Poland, and they liked the fact that they received prints afterwards. Our presence was also especially important to our hosts, not only for economic reasons (we paid for accommodation and food), and possible status increase (those strangers stay at my home, and not at my neighbours'), but also simply for the fact of having interesting strangers to talk to. Some power relations were unwillingly (and unconsciously) maintained, even though we always tried to treat participants as friends.

I further think we should prepare photos from our own life and environment to maintain a level of reciprocity of exchanged information. We should give the people we work with also the possibility to get to know us a little bit better and to satisfy their curiosity (although it is understandable that, in many cases, our photos should 


\section{perifèria}

Número 17, diciembre 2012

revistes.uab.cat/periferia

not be shown before we have finished our photo work, as it could influence the participants). ${ }^{12}$

An important issue is the inadequacy of the technology being used. There were several situations in which project participants did not have any experience in taking photos, usually in the case of older people. In some cases the participants managed to use the camera after a few unsuccessful attempts, and in other they used it with the help of their children or grandchildren. One of those situations was especially crucial, as a man (very friendly) after an interview refused to make photos saying he "does not know how to do it." I assumed this meant he didn't understand my explanations about how to take pictures, so I explained twice again how to push the shutter button of the fully automatic camera. But again and again he claimed he "does not know how to do it." Then I understood that it was about the camera itself. It was an object that did not belong to his reality. It was not a problem for me to take pictures. To him the camera was as strange as myself, so I was allowed to take pictures of him and his wife. He was already used to the situation of interview and "strange questions" because of the previous presence of anthropologists in this village, but taking his own pictures was something too strange. For this reason the technology used in visual participatory projects should be either adjusted to previous experiences, or precisely taught (which would change the character of research). Not only the technology, but also how much to teach about it, should be taken into account. In teaching how to use the camera, we also transmit our understanding and our way of using it.

The use of photographic technology gives some advantages; for example, it is easier than video, requires less preparation time, and needs fewer explanations. However, depending on the circumstances, it can be too difficult to use photography, for instance, in cases where the technology is not adjusted to the knowledge and existence of the participants (however, the experience of situations such as when the camera becomes something too strange for participants might also provide some interesting information). The photo shootings we arranged were rather short ones. We always accompanied the photographers during their photo shooting. This provided us with information about the performativity of taking

\footnotetext{
${ }^{12}$ An interesting example of peoples reactions to images brought by anthropologist is a great film made by Barbara Keifenheim and Patric Deshayes "Naua Huni - Indianerblick auf die Andere Welt" (1984), They recorded Kashinawa audience responses to a film about the Ruhrgebiet (a German coal mining and industrial area).
} 


\section{perifèria}

Número 17, diciembre 2012

revistes.uab.cat/periferia

photos, but it does not leave them free to photograph in more private circumstances. I think the ideal method would be to do both and leave the cameras to the participants for some time. We did not do this because we had only two cameras for the participants. I consider it as a mistake, in retrospect, not to have allowed time for individual (unaccompanied) photo shootings.

An advantage of the method of "participatory photography" is the possibility of giving explanations of what we see or understand differently. Many times participants made photos I understood in a completely different way than they did. It was a result of my different experiences and, often, my stereotypical thinking. After explanations by the participants, I discovered completely different connotations with the subject of the pictures.

A very good example is a picture taken by our first host, one of the friendliest persons we met - Alfredo, a tailor and a possible prospective shaman. One of the very first photos he made, just after a photo of his workspace and his daughter (the order of taking photos also provides important information about participants' priorities), was a photograph of the small creek behind his house.

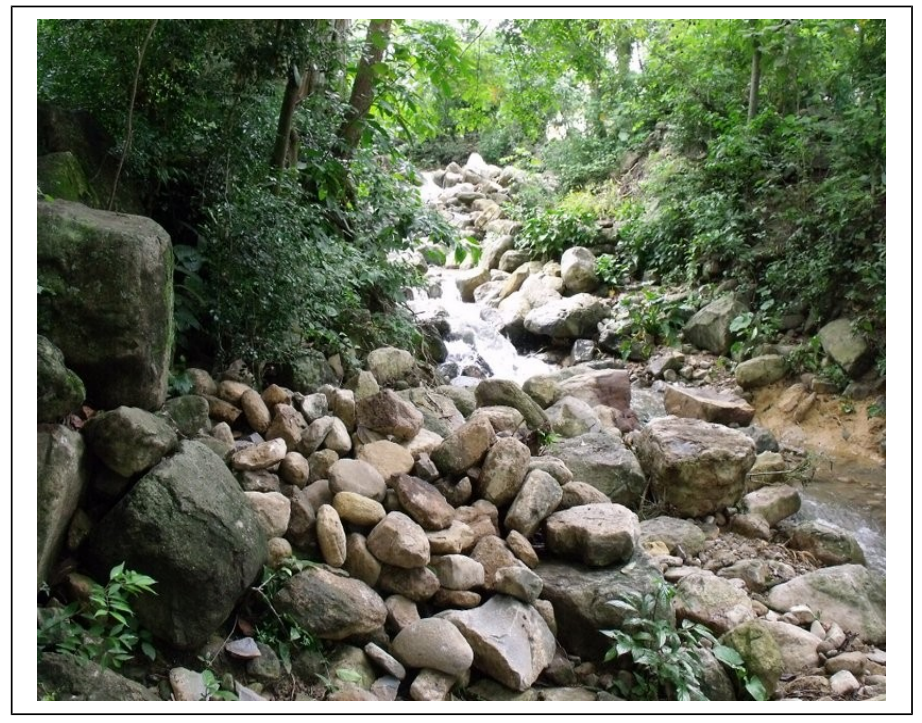

(photo: Alfredo Hernandez Maria)

I thought that he was emphasizing the importance of having a source of water nearby, which is used for cooking, cleaning, dishwashing and so on. But later, while talking about the photos, Alfredo mentioned the danger and worries related to the creek. During the rainy season, the level of water rises dramatically, and there have 


\section{perifèria}

Número 17, diciembre 2012

revistes.uab.cat/periferia

been floods in the past. The water supply was only a secondary reason. He saw something else, a different reality, looking at the creek. This photographic experience not only revealed the different perspective, but also changed my own perception of the creek.

Other examples were photos taken by Doña Maria Guadalupe, a 63-year-old woman from the village of Hueycuatitla. She first took pictures of her grandchildren.

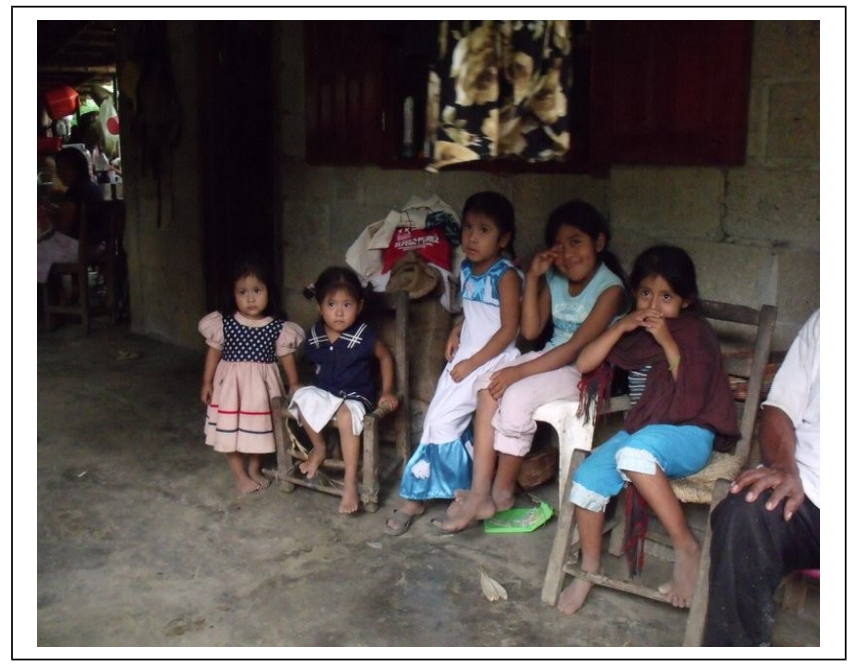

(photo: Maria Guadalupe)

But when she started to speak about this photo, she immediately began to describe her children and the conditions of obstetrics and medicine during "her times." She gave birth to 11 children, but 5 of them died during the birth or as infants. What ambiguity of emotions is provoked by the picture of her grandchildren? She treated them with care, and it was obvious that they are dear to her. However, at the same time they provoke memories of her own losses and pains. Here photography helped to provoke some very personal and emotional utterance. I do not know if such experiences would have been discussed so quickly if she had not been describing a picture.

Photos like the previous grandchildren of Doña Maria Guadalupe are understood by the participants in terms of emotions and family. Other photos have the purpose of showing a concrete object (a sort of photographical deixis) - "look at this," "I want you to see this." Examples are photos taken by Maria Magdalena Hernandez, a very humorous 65-year-old woman from the village of Hueycuatitla. Before taking 


\section{perifèria}

Número 17, diciembre 2012

revistes.uab.cat/periferia pictures of her family, and later of her religious artifacts, she took a picture of her own house and the house of the neighbour across the street.

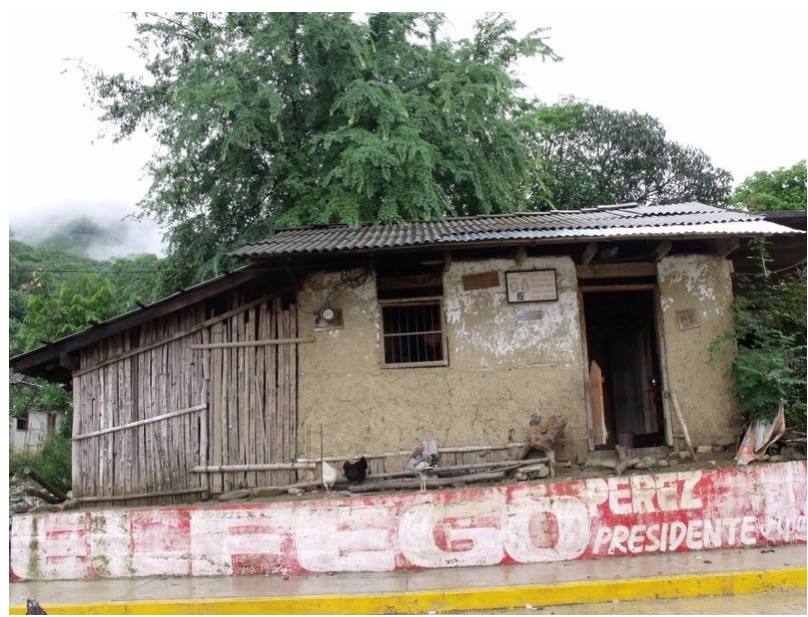

Doña Hernandez's house (photo: Maria Magdalena Hernandez)

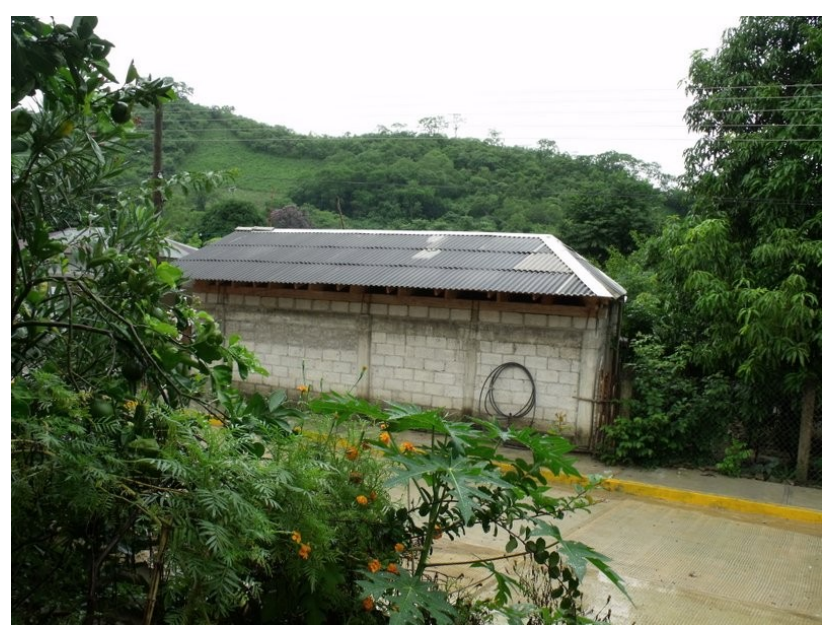

The neighbour's house (photo: Maria Magdalena Hernandez)

"I don't like my house" explained Doña Hernandez, "it is ugly and old." And then referring to the second picture, she explained, "this is the house I would like to have, if I had enough money". She showed the differing value of new and traditional construction methods, and how the neighbor "is in a better situation" (aesthetical values and economic differences).

I will now present three English translations of "portraits from inside" created during the project, just to give a glimpse of the final results. In total there are more than 40 "portraits", and they can be found (in Polish) on the website of the project: www.od-wewnatrz.pl. Even though this method focuses on individuals, one can get some ideas about the community of people after looking at the pictures and comments of many individuals. 


\section{perifèria}

Número 17, diciembre 2012

revistes.uab.cat/periferia

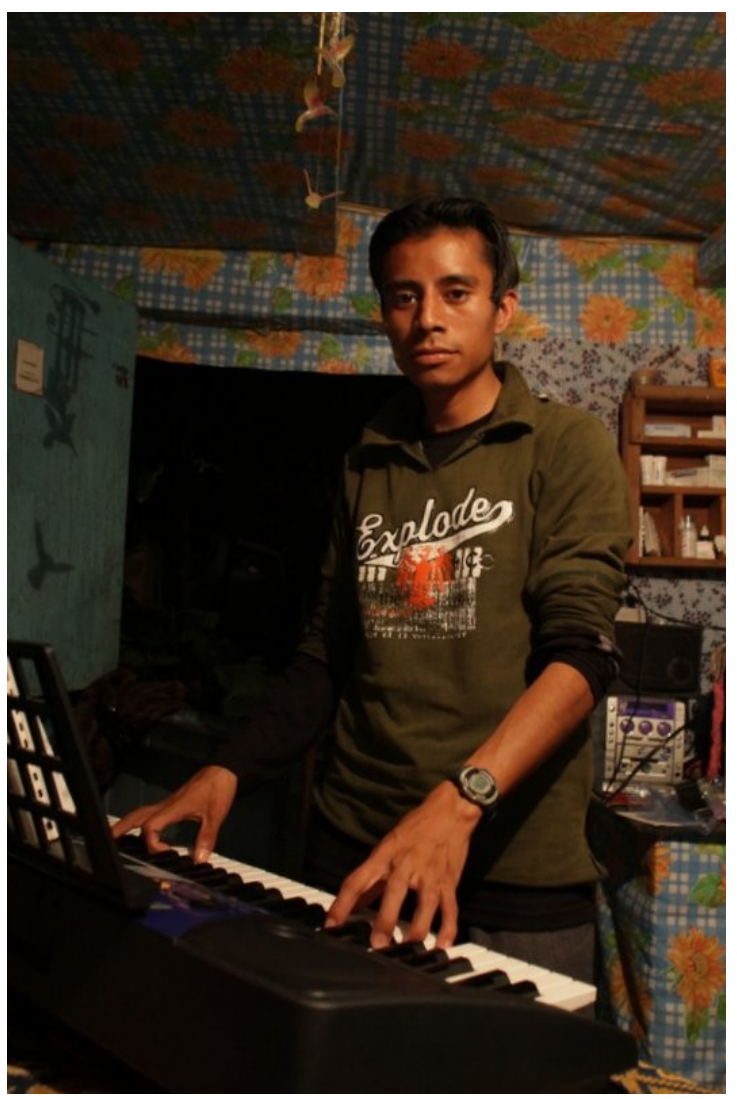

\section{Benito}

gender: Male age: 25

photographic experience: does not possess a camera, but has taken

pictures before

region: Highlands of Chiapas

place of birth: Chimtic

place of residence: Las Limas

education: high school, still a student marital status: married children: 1

Benito decided to have his portrait photo with his electric keyboard instrument, which he values a lot.

Benito is the youngest of 9 children of our host in the village of Las Limas - Don Victorio. He was very helpful; he spent a lot of time with us, and translated the interviews we made with people who did not speak Spanish. He was also very curious about Poland and Europe.

-Where (how?) do you work?

-I don't work, I'm a student. Last year I finished my high school and now I'm doing a social service in a health center as a teacher. I teach children, in general subjects like mathematics. Later I want to go and study medicine at the university in Guadalajara. I'm searching now for a possibility to do so. I want to go to Guadalajara because the education in San Cristobal is too corrupt, and in Guadalajara the professors do not accept any bribes. I wish to take my wife and my child with me.

-How is your house? How would you describe it?

-It's my father's house. This is only my room. I like how it is constructed. 


\section{perifèria}

Número 17, diciembre 2012

-How many people live in it?

\section{revistes.uab.cat/periferia}

-Me, my wife and my child.

-What do you do during your free time?

-I like to play chess very much, and I also like to play my keyboard.

-What is your favourite activity, what do you like most?

-I look forward to my studies. I don't like to work in the fields, because in the fields you suffer a lot. When I go to the fields, and observe others working, I see how much they suffer... It is very difficult to work in the fields. And I don't like it, because one does not earn any money, only produces the food.

What makes you happy?

-I'm happy when I'm not sick, and when I see that I am achieving my goals. I'm happy to finish my preparatory school [high school], and to finish soon my hospital social service.

-What usually makes you sad?

It makes me sad to see how my dad is ageing. When my parents will die I will be left alone. And seeing how he only works in the fields makes me sad... and I don't... I don't help them in the fields, because I'm a student, and sometimes we have conflicts with my dad, because he tells me "you're not working in the fields". And that makes me very sad sometimes... and... No one helps me.

-What are your future plans?

I want to become a doctor. I want to help people, and earn money to support my family. And I will be able to give hand to my mother, my father, my brother... because I have a plan! And also when they get sick I will already have experience and I will know what medicine to apply. This is my plan.

-What kind of dreams or wishes do you have?

- I would like to have a car and a nicer, bigger, home. And I wish to help my child, when he will be 6 or 7 years old, with the education. I wish to support him with university studies, so he will not have to suffer like I do.

\section{Pictures taken by Benito:}




\section{perifèria}

Número 17, diciembre 2012

revistes.uab.cat/periferia
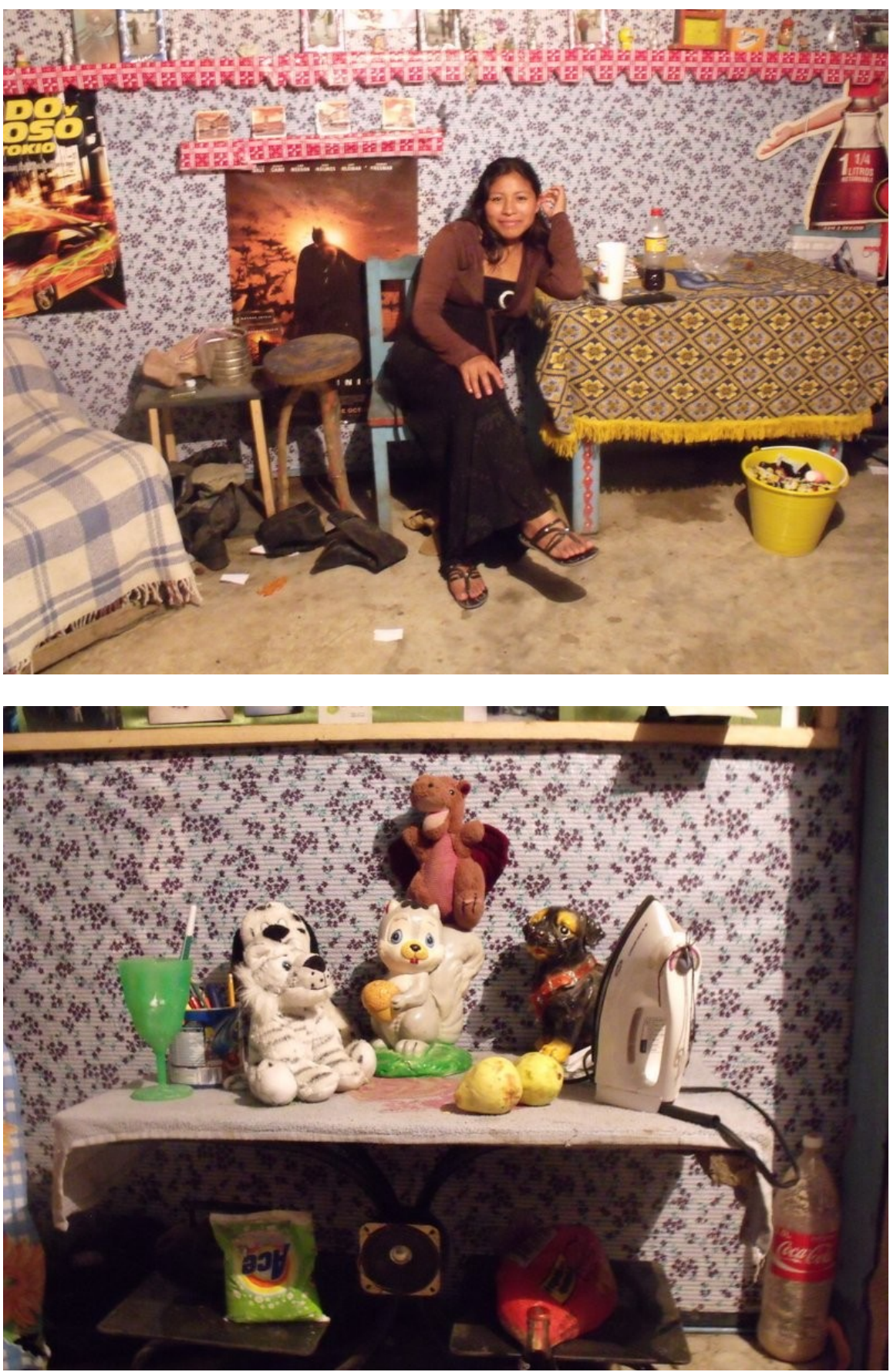

This is my wife,

Yolanda. She is very beautiful.
Teddy bears look very nice, and I like them a lot.

Commentary: those teddy bears are not toys of Benito and Yolanda's child - they are more a decoration and objects of high aesthetical value. 


\section{perifèria}

Número 17, diciembre 2012

revistes.uab.cat/periferia
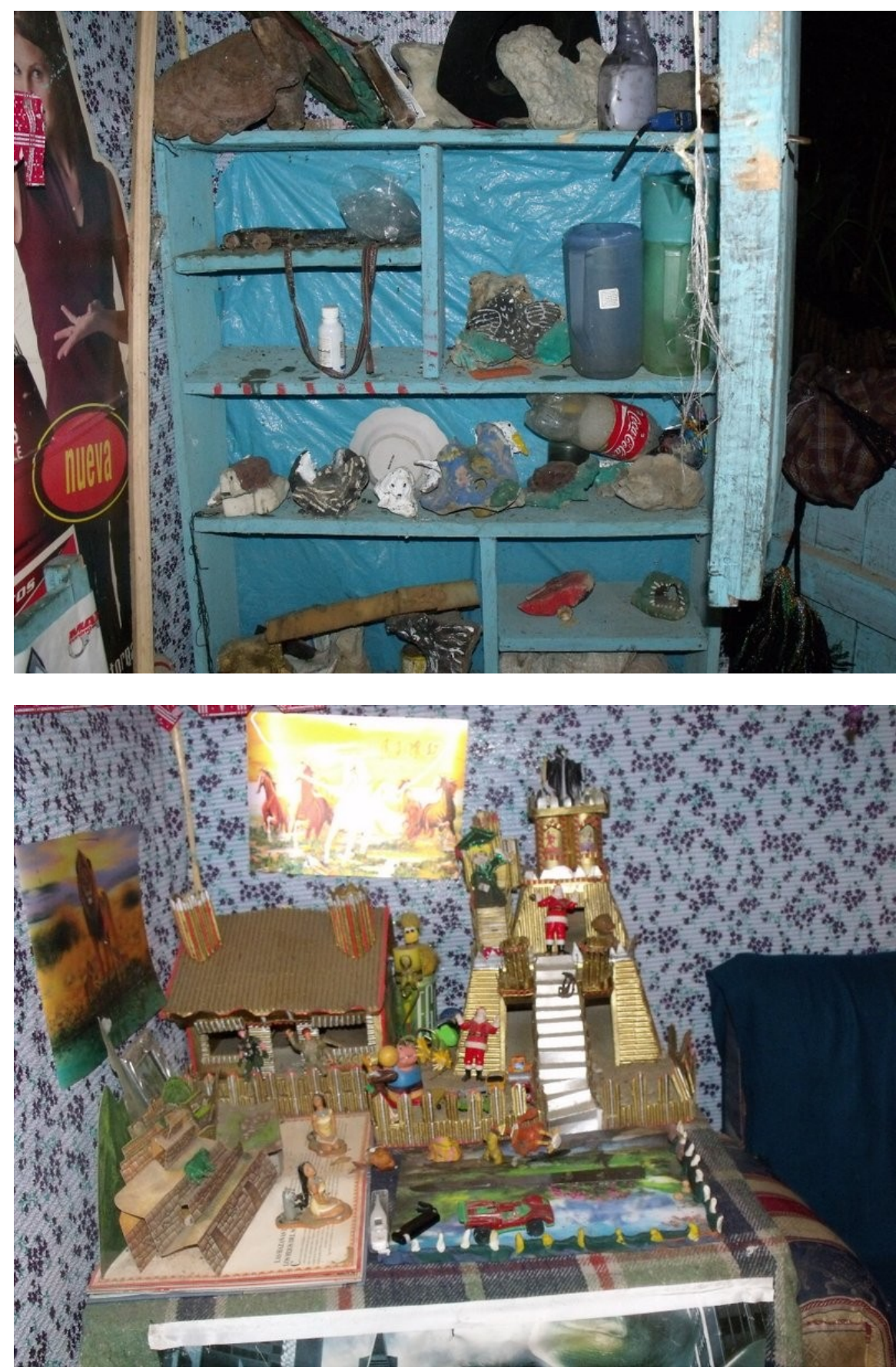

I don't like this because it is ugly, untidy and it is a mess.

I've done it by myself and I like it a lot.

Comment: this was displayed in a corner of his room, but in such a way that every visitor could see it right away. 


\section{perifèria}

Número 17, diciembre 2012

revistes.uab.cat/periferia

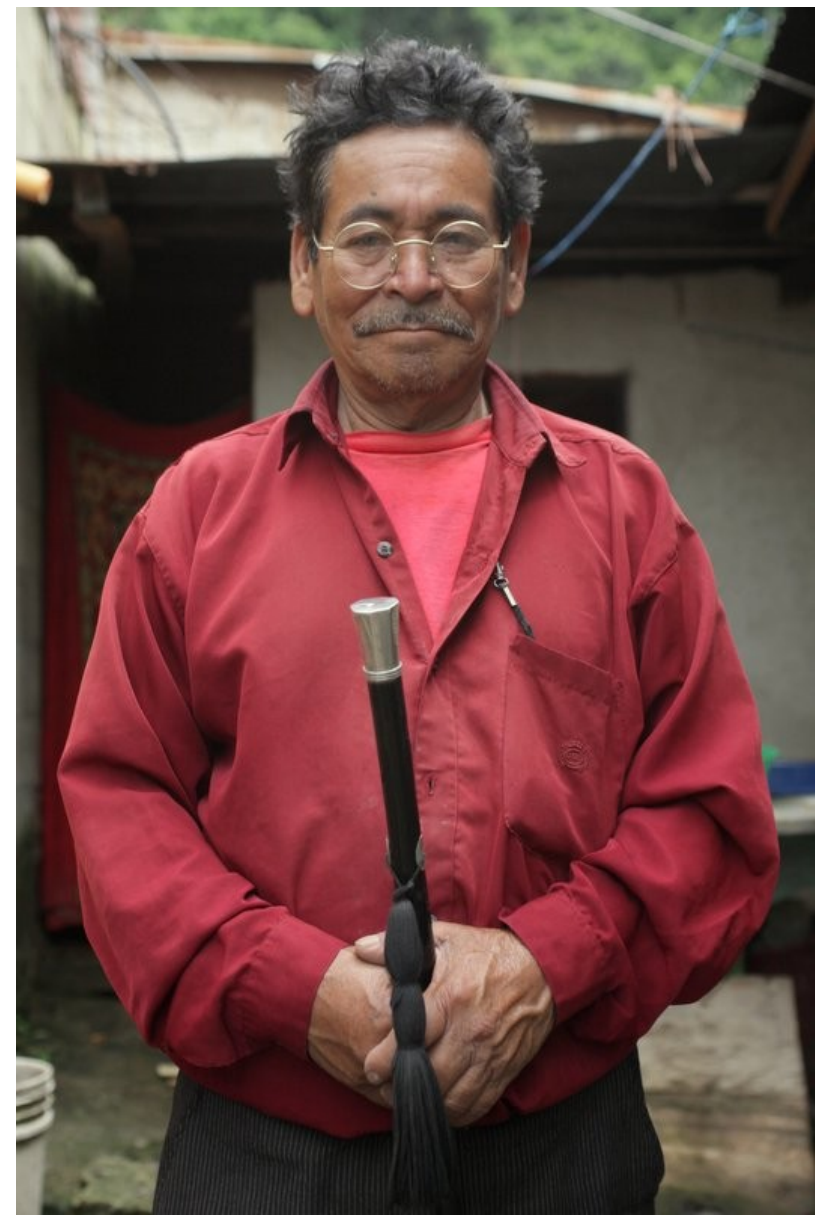

\section{Eustacio Corollon Pos}

gender: Male age: 75

photographic experience: none, but he wanted me to teach him

region: Municipio Solola

place of birth: San Jorge la Laguna place of residence: San Jorge la Laguna

education: none marital status: widower children: 9

(62 grandchildren and 28 great-grandchildren)

Eustacio decided to have his portrait photo with the staff that is a symbol of the municipal mayor.

When we came to San Jorge la Laguna, we went to ask the authorities for permission to do the project (this is an important act of recognition of authority). That's how we met Eustacio. He was happy to welcome us, and to show us the village and his house.

-Where (how?) do you work?

-This year I stopped to work. I can't bear it anymore. But I am a constructor. I'm a foreman. I'm a foreman! I'm the one who makes plans. I have had workers working for me. I'm the one who manages. I built 3 houses here [in San Jorge la Laguna]. But I also worked in Guatemala [city], Solola and in Panajachel. I made houses with 3 levels! I started to work when I was 17 years old, first as stonemason. Then I worked and worked... and I became a foreman! But not anymore. I'm afraid of climbing the construction site now. 


\section{perifèria}

Número 17, diciembre 2012

revistes.uab.cat/periferia

And to be a mayor... That is not work, you only have to talk with people. You only talk, there is no work, there is no movement, there is nothing - you just sit around.

-How did you learn to do your work?

-I learned it all myself. I built a house here, without knowing anything, I wasn't even a mason. I studied it myself and then I made a house of two levels. I'm also a hewer and a plumber.

I have not studied at all, but I know how to read a little bit.

-How would you describe your house?

-It's a one level house. I have four flats. The other flats are smaller. I gave them to my children, and I have a quarter of the house for my own. We live four at this house -me and three of my sons. And they live here with their children. But my flat is separated, so no one disturbs me.

-What do you do during your free time?

-Nothing. I rest. I sleep, or I do something in the house. So I rest. Or I go to see the fields. I have fields, and workers that work there. But I don't work in the fields.

-What is your favorite activity?

-I like to convene with people. To give them ideas. I like to give ideas for the mankind. I have a lot of experience to be able to talk with people, help them. It's the second time I'm elected for mayor.

We divide the work in the municipality in turns, but I take more turns as I don't work anymore and I have more time.

-Which moments of your life do you consider more important?

-My life...only God knows it. But about the past... I was drinking a lot in the past... But then I stopped drinking. I was thinking a lot. I can't be like this - drunk - and have kids. What teaching am I doing? If one day my kid will get drunk, he will tell me "you have also been drunk, you have also been drunk!" I stopped to drink. I'm not drinking anymore. It has been already 37 years of not even a little drink. This was my past life. And I was a stonemason, a bricklayer, I was a foreman. And I have done a lot of service for the municipality. When I stopped to drink, I bought my land, I constructed my house. I have gained a lot, when I stopped to drink.

What makes you happy?

-What makes me happy in my life is not to drink. And I was happy in life, when I had a wife. Because a woman is the one who takes care of things in home, and there is someone to talk to. And I made myself really happy by quitting drinking. 


\section{perifèria}

Número 17, diciembre 2012

-What usually makes you sad?

revistes.uab.cat/periferia

-It makes me sad not to have a wife. Who prepares the food, who makes the laundry? I'm the one who makes my own laundry. My wife died seven years ago.

-What are your future plans?

-My plan is not to work anymore. No more constructions. I will not go to work anymore. I want to be comfortable in my house, so that no one disturbs me. To live in this world is happiness. To die is to gain. To die is to rest.

-What kind of dreams or wishes do you have?

-I have a wish but there is no money [Spanish "plata" is more colloquial then "money"]. I would like to travel to other countries. Any country. Poland [he laughed]. I went once to Venezuela, to Caracas. I would like to travel more 


\section{perifèria}

Número 17, diciembre 2012

revistes.uab.cat/periferia

\section{Pictures taken by Eustacio:}
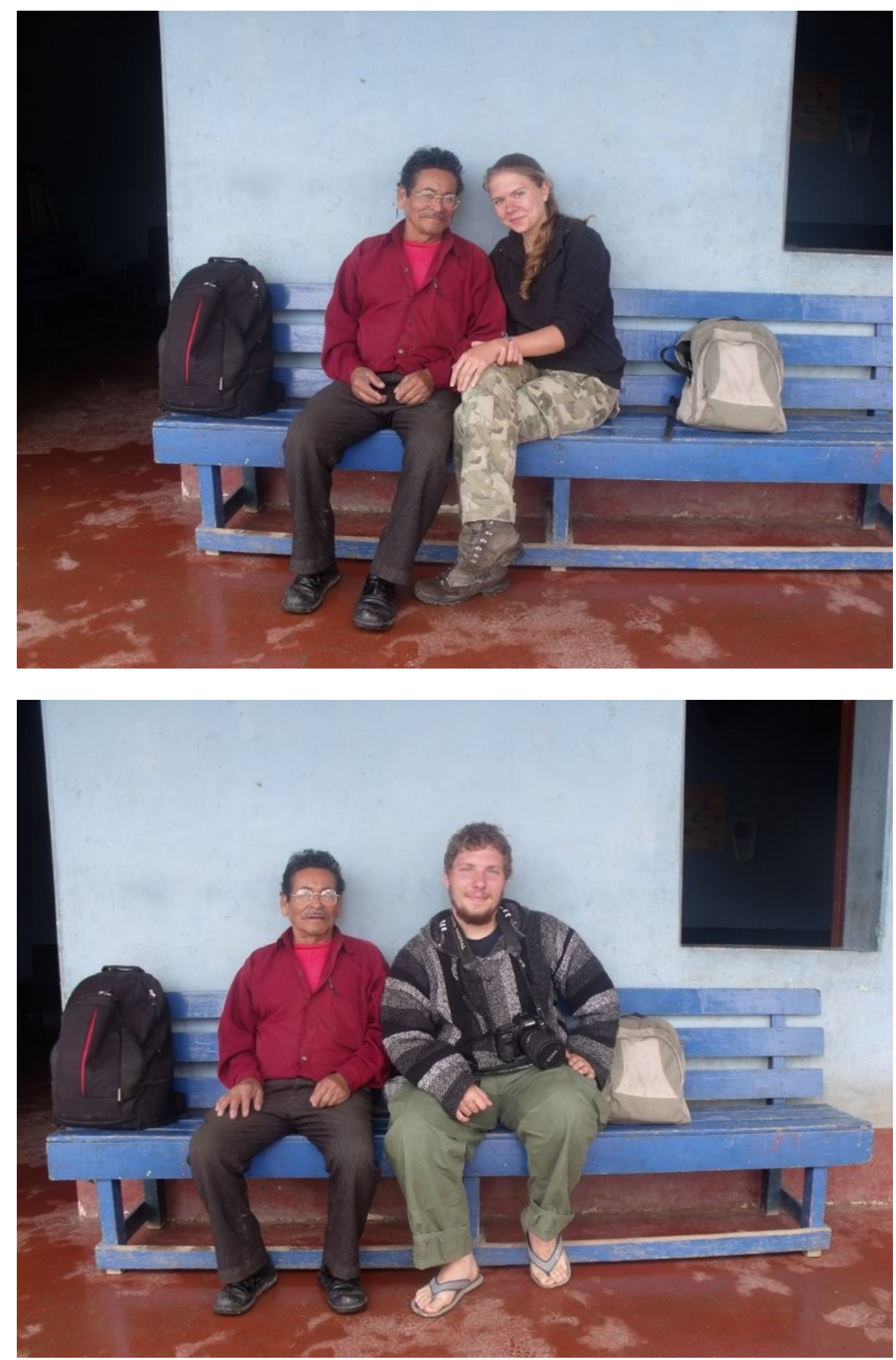

I want to have a reminder of you both.

Comment: Eustacio passed the camera first to me and then to Maria, and asked us to take photos with him. 
perifèria

Número 17, diciembre 2012

revistes.uab.cat/periferia
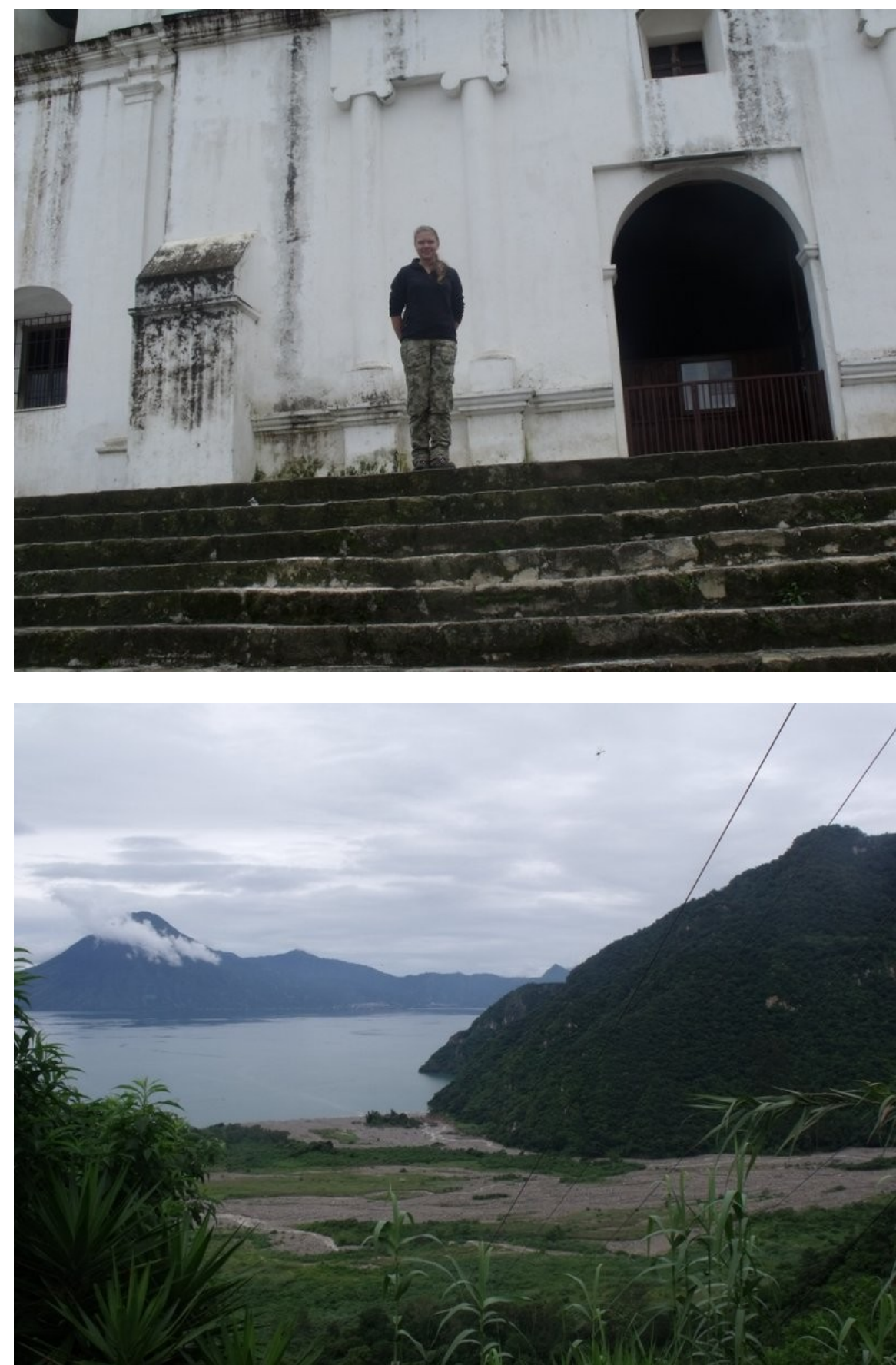

I see this church every day, and you don't. So I made this photo for you.

Comment: Eustacio asked Maria to pose in front of the church. It is the oldest and biggest building in the village.

This is our landscape. I made a picture of the lake for you, to take it to Poland. 
perifèria

Número 17, diciembre 2012

revistes.uab.cat/periferia
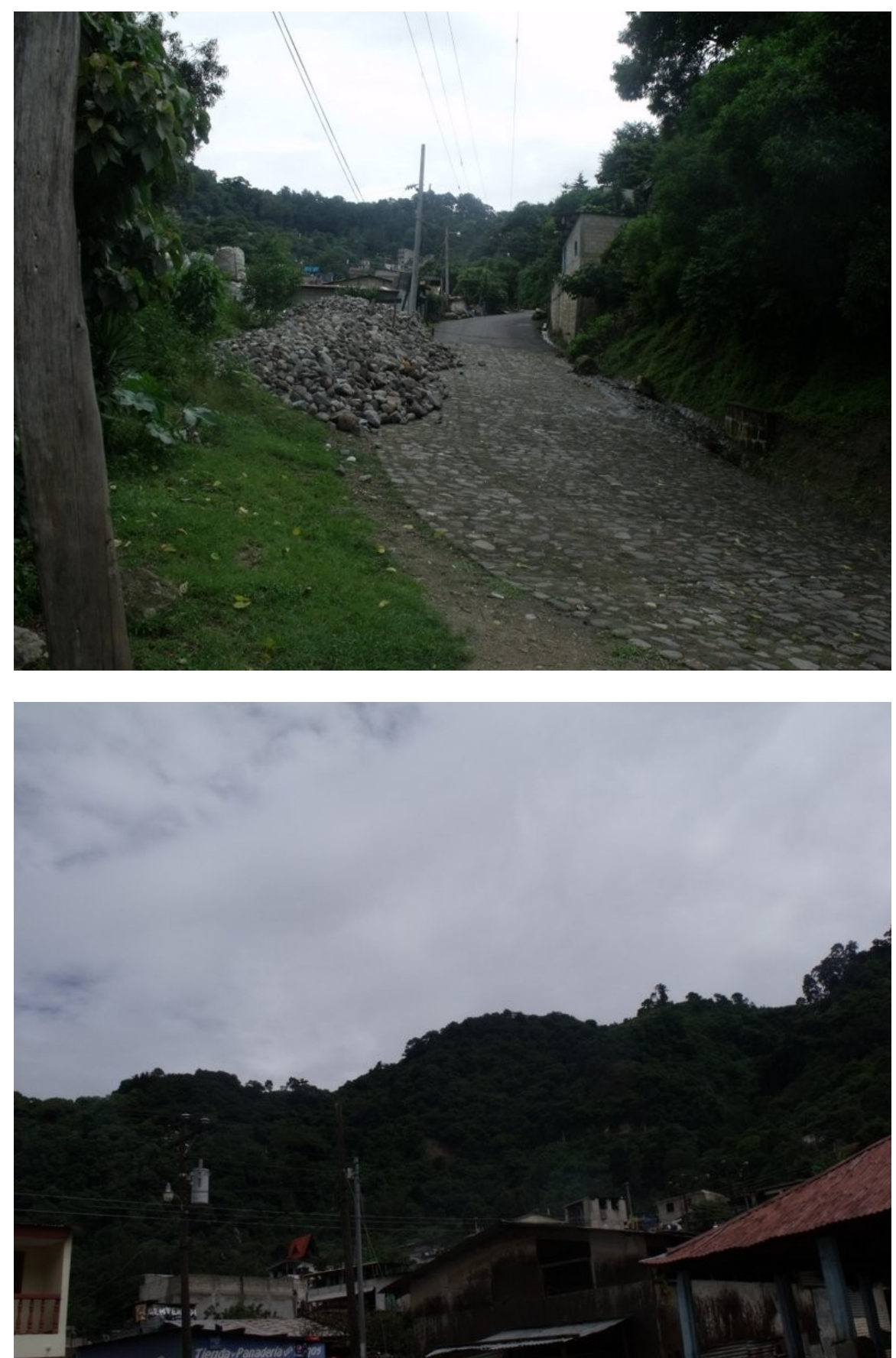

This road is terrible and useless.

There are many dangerous landslides.

Comment: The landslides are a huge problem; they cause lots of damages and sometimes even death. 


\section{perifèria}

Número 17, diciembre 2012

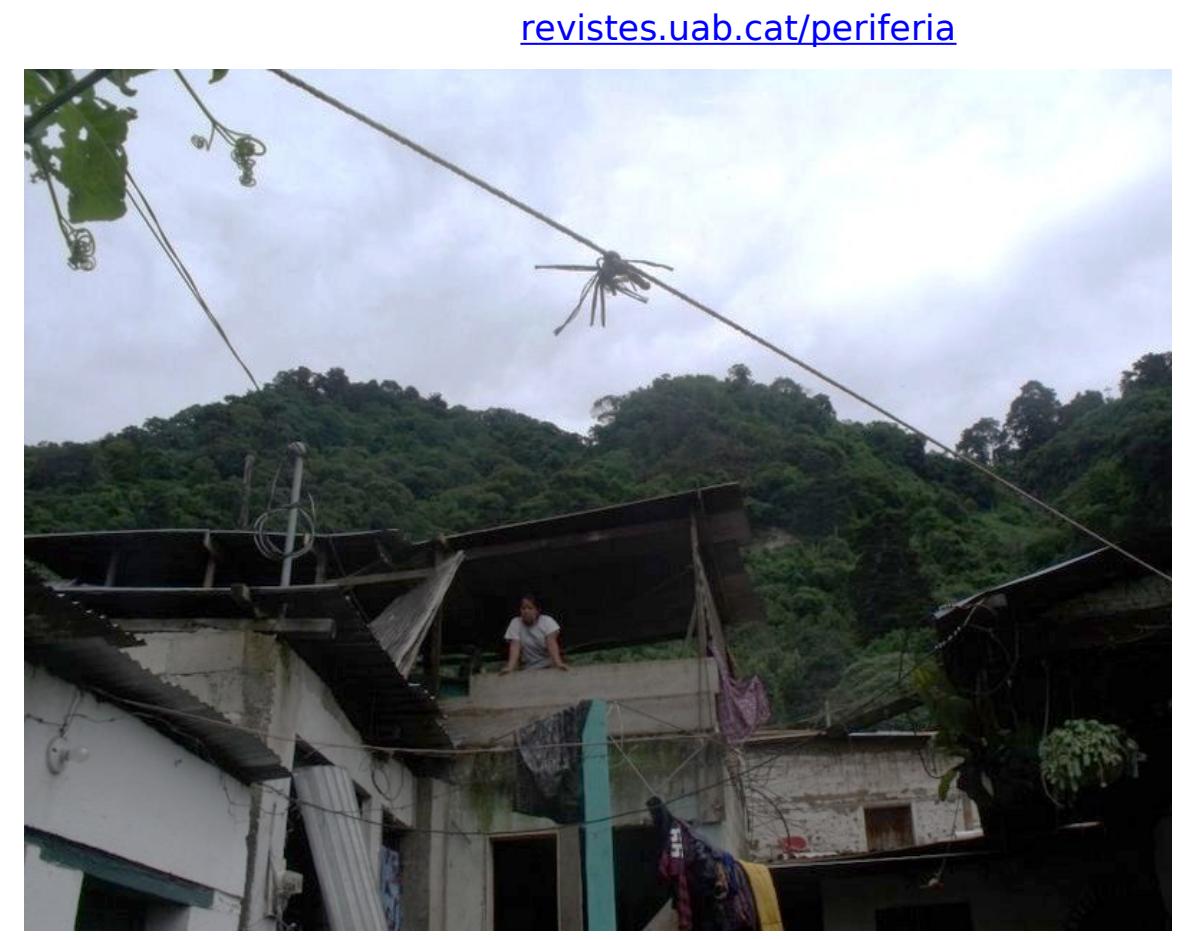

This is my home...

During the project, we also gave the cameras to children playing in the villages. It was not part of the project plan, and unfortunately we did not pay a lot of attention to this issue. Nevertheless, I made a few observations which merge with François Soulages' analysis of Marc Pataut's project (Soulages 2007: 182-196). When we gave cameras to groups of children (situations in which an individual child was given a camera were a little different), it became an object of games and interactions. The joy and emotions of making pictures appeared more important than the images themselves. Making pictures of others could be compared, recalling Soulages, to a toy pistol shooting - "I shot you," "I captured you"- as a matter of provoking interaction, where the moment of shooting is more important than the result. "I see you! Do something!" Children also interacted with adults who passed through the place where they were playing. The interaction aspect was the most important. That is why all the pictures taken by them are pictures of others passing by or of other children, including many close-ups of their faces or of body parts there were no pictures of places or things. 


\section{perifèria}

Número 17, diciembre 2012

revistes.uab.cat/periferia

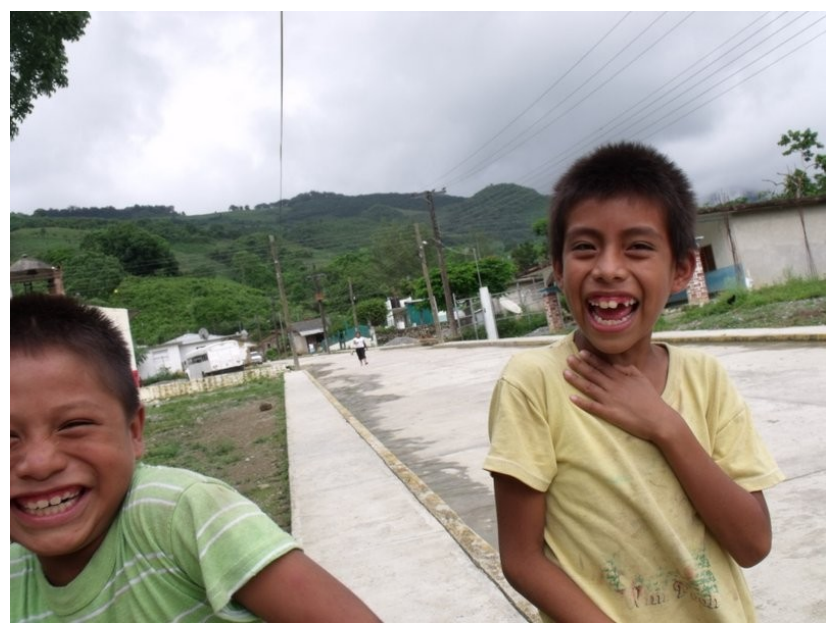

Photography was a tool for fun (photo: Children of Hueycuatitla)

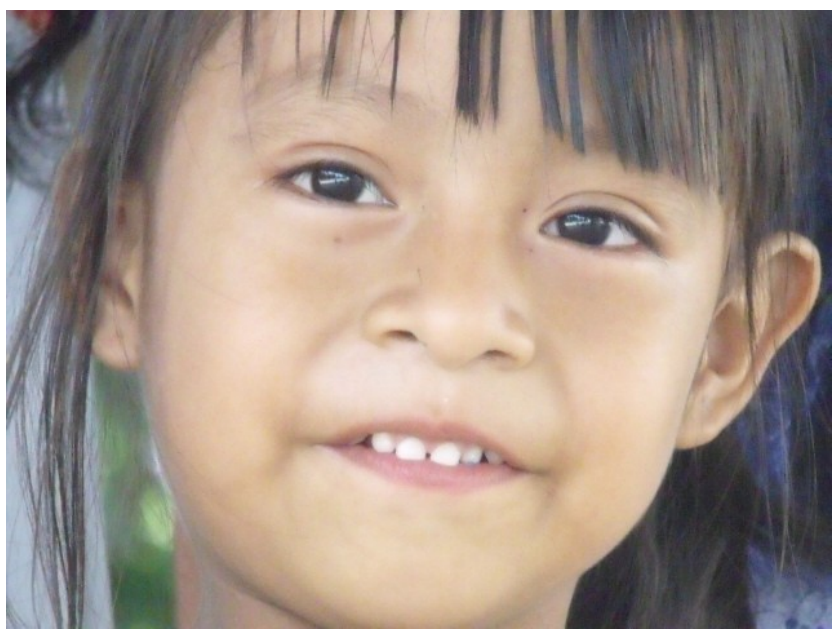

Many face close-ups were taken... (photo: Children of Hueycuatitla)

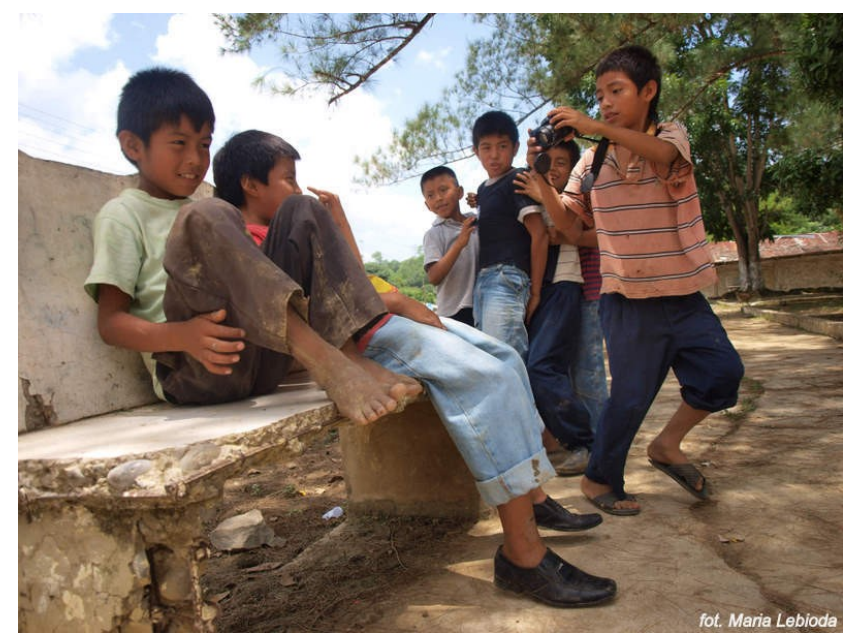

Photography was a tool for interactions (photo: Maria Lebioda)

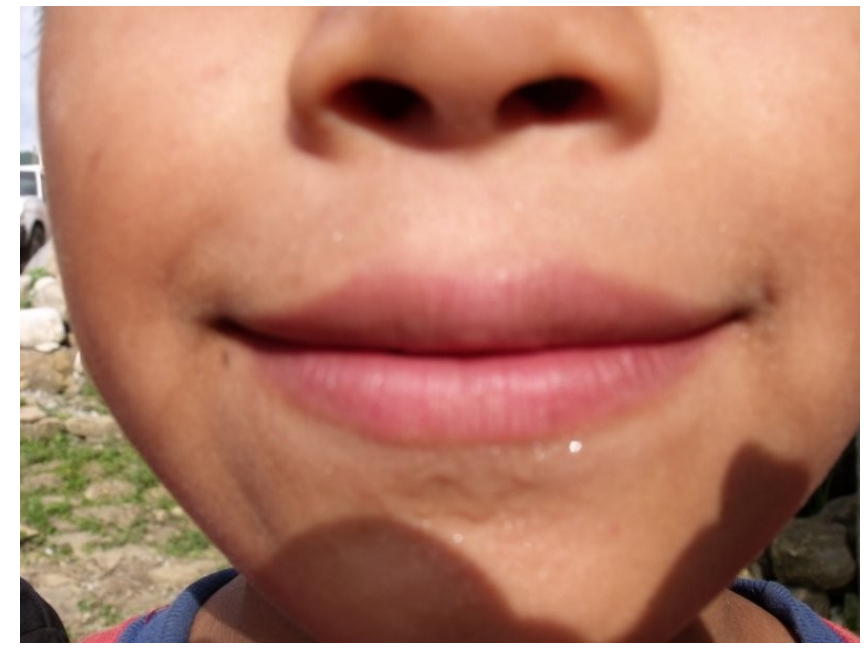

...as well as body details (photo: Children of Hueycuatitla) 


\section{perifèria}

Número 17, diciembre 2012

revistes.uab.cat/periferia

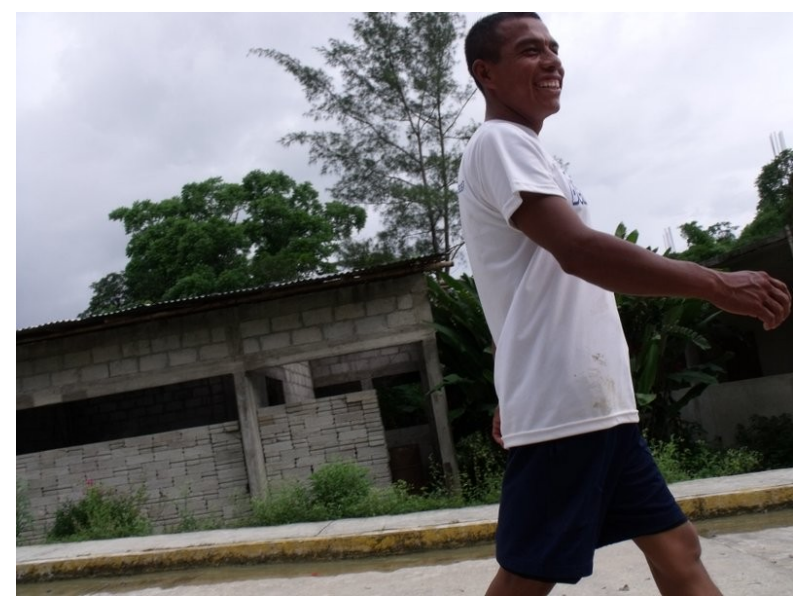

Through photography interaction with passing by adults was possible (photo: Children of Hueycuatitla)

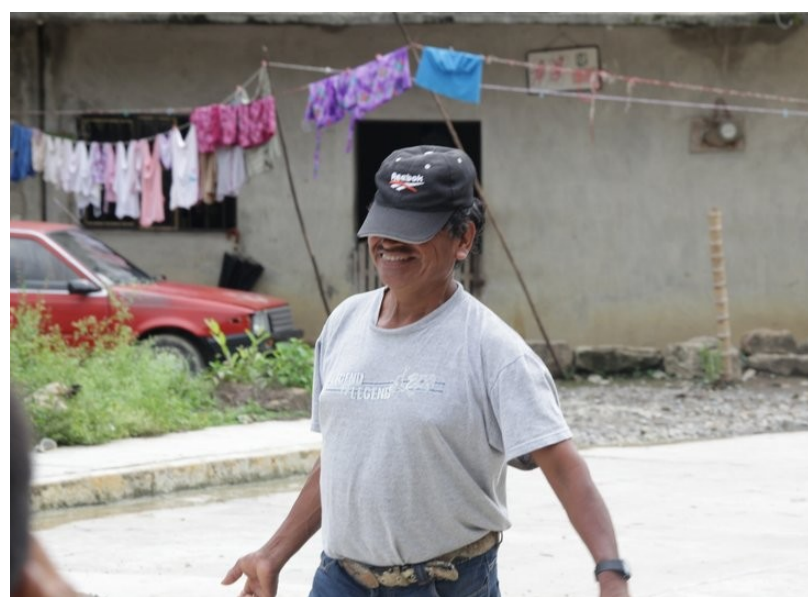

The man responded to the "photo provocation" and "did something" (photo: Jonatan Kurzwelly)

Another issue that emerged from the photography situations with children was the question of who should be considered the author of those photos. Many of those photos are created during the play; the camera was passed from hands to hands, sometimes the shutter button was pushed accidentally, or by two children at the same time. In these cases it is not possible to define one author, as the pictures are results of the whole group's interaction. In this case I do believe the author is collective. ${ }^{13}$

\footnotetext{
${ }^{13}$ Authorship is not a universal concept and for those children it was not important at all.
} 


\section{perifèria}

Número 17, diciembre 2012

revistes.uab.cat/periferia

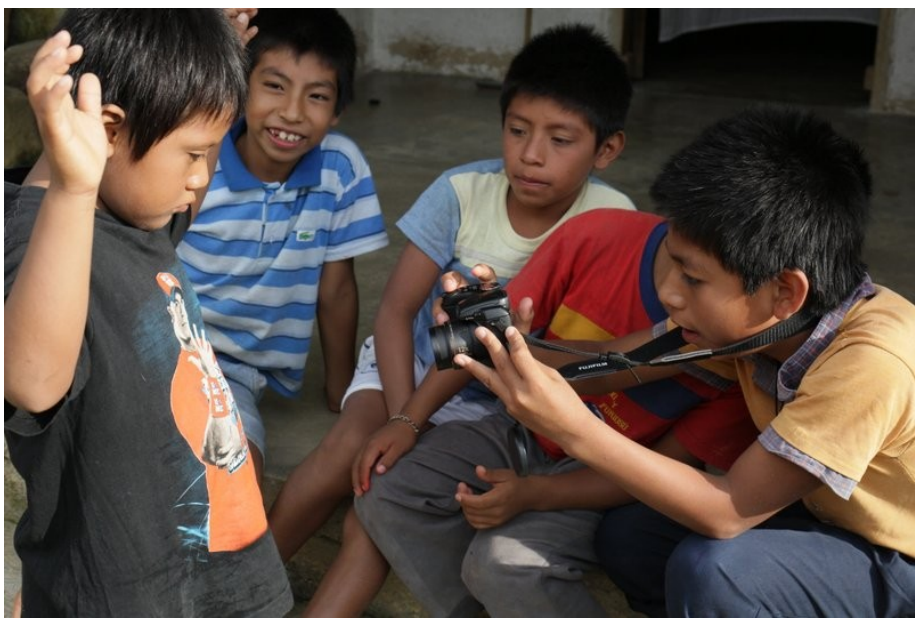

In this situation the camera has been passed to the children by me. The person with camera was asked to make a photo of the t-shirt, one child instructed the other about the composition of the frame, and finally the third boy pushed the shutter button. The whole situation was a result of the play of all of the boys together. (photo: Jonatan Kurzwelly)

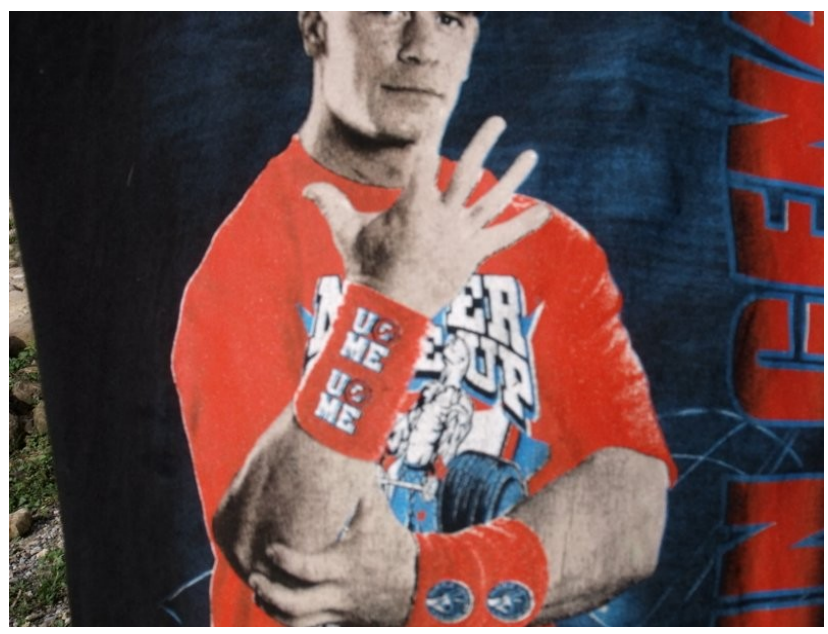

An example of an image with collective authors. This picture and the situation in which it was made provide us information about the idols of Nahua children from this village, about the value of this concrete t-shirt and its role in self-representation.

(photo: Children of Hueycuatitla)

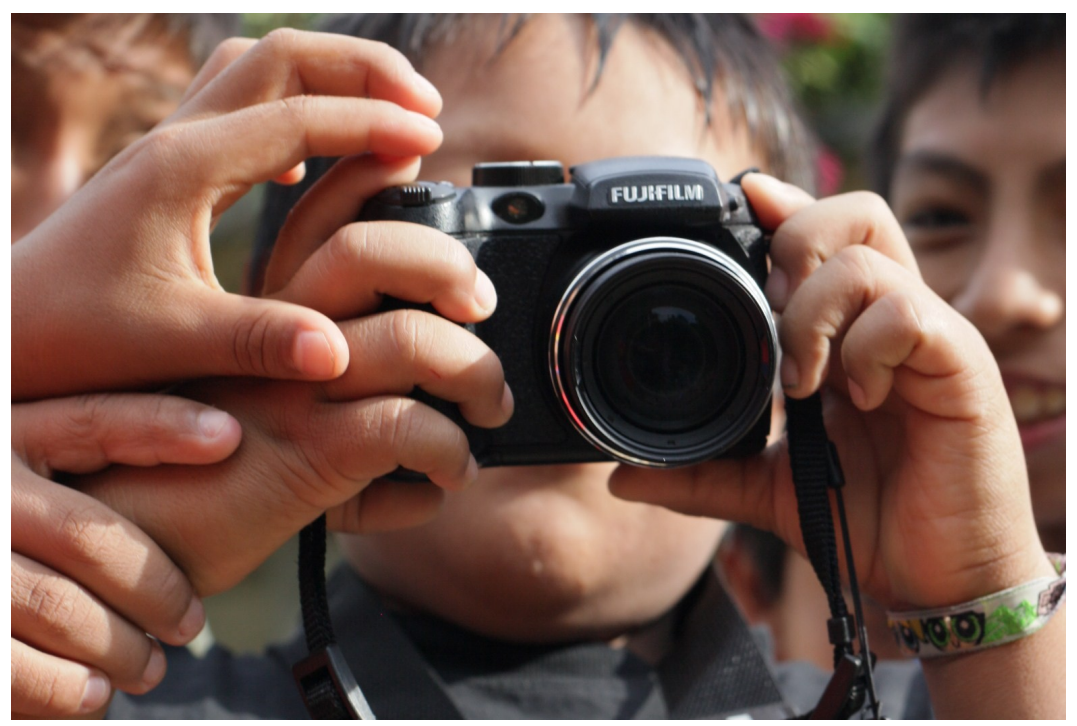

(photo: Jonatan Kurzwelly) 


\section{perifèria}

Número 17, diciembre 2012

revistes.uab.cat/periferia

\section{Conclusions}

There is no objectivity in perception. Every person has his or her own unique reality (perspective). One objective reality does not exist. Even if an ontologically objective world exists, we do not have proof of it and no access to it. It does not exist for us. No one is an outside viewer. Our bodies and experiences determine our perspectives.

Moreover, we see ourselves through interaction with others. The others are like mirrors to us and to each other. By seeing the different others (through our perspective), we become conscious about ourselves, and about what distinguishes us. We do not have "direct access" to others or to their realities. That is why experience is necessary. During more intensive interactions, we change our perspective of others, and we can try to understand theirs. What participatory photography can add to this process is trying to learn by pictures and their descriptions what the world of the other is like.

Many previous discussions about photography have tried to describe the uniqueness of this technique to establish its particular "relation with reality". But photography is no magic indexical "trace." It is as subjective as language or painting. Truth claims made on the basis of images are agreements about meanings. However this fact does not undermine the informational value of photographs. Individual meanings of photographic pictures can be transmitted by explanations. That is why taking pictures for purposes of communication requires language and experience.

In social and cultural anthropology the quality of obtained knowledge about "others" depends on experience. Tarzycjusz Buliński and Mariusz Kairski (2011) propose the evaluative term thick experience. The thickness of experience depends on time spent interacting, partners of interaction, and intensity of interaction. I agree with them that long-term interactions with high frequency and with many partners provide more experience than short term research. The third quality of thick experience is intensity of interaction. Intensity that involves all senses (not only sight, and also not only discussion), and the intensity of engagement in the interaction.

Participatory photography combines discussion and explanation of perspectives with sharing visual experiences. It often demands more engagement than only 


\section{perifèria}

Número 17, diciembre 2012

revistes.uab.cat/periferia

interviews, as both researchers and participants collaborate in taking pictures. Those pictures can later be used for expositions or just to enrich the collection of family photos - a "product" is created as a result of interaction. Well-used participatory photography has many advantages. I do not claim superiority for this method; my goal is just to show its utility.

Only some aspects of participatory photography have been presented in this essay. It is not a manual. Much more could be said about this method, and still a lot has to be tested and examined. However I hope it might be useful for anyone who is planning a participatory photography project.

\section{References}

Banks, Marcus (2009). Materiały wizualne w badaniach jakościowych, Wydawnictwo Naukowe PWN.

Banks, Marcus and Ruby, Jay (2011). Made to Be Seen: Perspectives on the History of Visual Anthropology, The University of Chicago Press.

Barthes, Roland (1996). Światło obrazu, Uwagi o fotografii, Warszawa.

Brauchitsch von, Boris (2994). Mała historia fotografii, Cyklady.

Buliński, Tarzycjusz and Kairski, Mariusz (2011). "Wiedza terenowa w antropologii. W poszukiwaniu nowego wymiaru badań terenowych" in Teren W Antropologii. Praktyka badawcza we współczesnej antropologii kulturowej, pp.291-333, Wydawnictwo Naukowe Uniwersytetu im. Adama Mickiewicza.

Collier, John Jr. and Collier, Malcom (1999). Visual Anthropology: Photography as a research method, University of New Mexico Press, Albuquerque.

Edwards, Elizabeth (1994). Anthropology and Photography, 1860-1920; Yale University Press.

Edwards, Elizabeth (2001). Raw Histories: Photographs, Anthropology and Museums; Berg Publishers.

Edwards, Elizabeth (2011). "Tracing Photography" in: Banks and Ruby, Made to Be Seen: Perspectives on the History of Visual Anthropology, The University of Chicago Press.

Ewart, Elizabeth (2008). "Seeing, Hearing and Speaking: Morality and Sense among the Panará in Central Brazil“ in Ethnos: Journal of Anthropology, 73:4, 505-522. 


\section{perifèria}

Número 17, diciembre 2012

revistes.uab.cat/periferia

Frizot, Michel (1998). A new history of photography, Koln.

González Granados, Paula (2011). "Tú mira la foto, pero no se la enseñes a nadie", Análisis de la práctica fotográfica, los discursos y las representaciones de niños y adolescentes en el contexto de talleres de fotografía participativa. Dos estudios de caso", doctoral thesis, unpublished, Universitat Rovira I Virgili, Tarragona (Used with Paula's permission)

in

http://www.tesisenred.net/bitstream/handle/10803/51883/TESISTDX_Paula

$\% 20$ Gonzalez.pdf?sequence $=1$ (accesed: 10.05.2012)

Gunning, Tom (2004). "What's the point of an Index? or, Faking Photographs", in Nordicom Review

$1-2$, http://www.nordicom.gu.se/common/publ_pdf/157_039-050.pdf (accessed: 24.04.2012).

Kohn, Eduardo (2007). "How dogs dream: Amazonian natures and the politics of transspecies engagement", American Ethnologist, Vol. 34, No. 1, pp. 3-24.

Packard, Josh (2008). "I'm gonna show you what it's really like out here': the power and limitation of participatory visual methods", Visual Studies, 23: 1, $63-77$.

Pink, Sarah (2009). Etnografia wizualna, obrazy, media $i$ przedstawienie w badaniach, Wydawnictwo Uniwersytetu Jagiellońskiego.

Purves, Dale and Lotto, R. Beau (2011). Why We See What We Do Redux: A Wholly Empirical Theory of Vision, Sinauer Associates.

Sikora, Slawomir (2004). Fotografia między dokumentem a symbolem, Warszawa.

Sontag, Susan (1986). O fotografii, Warszawa.

Soulages, François (2007). Estetyka Fotografii, Strata I Zysk.

Stolze Lima, Tânia (1999). "The Two and its Many: Reflections on Perspectivism in a Tupi Cosmology“ in Ethnos, Vol. 64:1, pp. 107-131.

Viveiros de Castro, Eduardo (1996). "Images of Nature and Society in Amazonian Ethnology“, Annual Review of Anthropology, 25:179-200.

Viveiros de Castro, Eduardo (1998). "Cosmological Deixis and Amerindian Perspectivism“, Journal of the Royal Anthropological Institute (N.S.), 4: 469 -88.

\section{Films}




\section{perifèria}

Número 17, diciembre 2012

revistes.uab.cat/periferia

-“Born into Brothels” by Ross Kauffman and Zana Briski (2004)

-"Naua Huni - Indianerblick auf die Andere Welt" by Barbara Keifenheim and Patric Deshayes (1984)

\section{Photos made by cats (CatCam)}

http://www.kittyphotographer.com/ (accessed: 12.05.2012)

http://www.catcam.com/ (accessed: 12.05.2012)

http://www.youtube.com/watch?v=fhnminWywfw (accessed: 12.05.2012) 